\title{
Rethinking Public Service Broadcasting in the Age of Economic Pressures. A Case Study of Kenya Broadcasting Corporation.
}

\author{
Mr. Wafula Nyongesa* \\ Masinde Muliro University of Science and Technology MMUST Kakamega, Kenya
}

*Corresponding Author: Mr. Wafula Nyongesa, Masinde Muliro University of Science and Technology MMUST Kakamega, Kenya

\begin{abstract}
This Paper attempts to elaborate the general problems regarding the performance of public service broadcasting in Kenya, as a direct result of the liberalisation of the broadcast airwaves. The work is an assessment of the KBC's fulfilment of its public service mandate, the general hypothesis being that the $K B C$ has failed to fulfill its public service mandate due to its inability to remain financially stable and politically independent from the government of the day. The research examined management policies, programs and funding in order to discover whether current changes in the broadcasting environment have influenced KBC's fulfilment of its public service mandate. The assumption is that if the concept of public service broadcasting is shifting, commitment to the principles underlying public broadcasting will shift and therefore public broadcasters are no longer working along traditional lines. The research concludes that $K B C$ is facing dire financial constraints due to the lack of stable funding and the withdrawal of financial support from the government in the face of increasing competition from commercial broadcasters.
\end{abstract}

Key terms: Public Service Broadcasting, Funding, Liberalisation, KBC.

\section{INTRODUCTION}

In a democratic society the media play an important role as a 'forth estate', acting as watchdogs of politicians as well as of other influential groups and people in society (Trappel et al, 2011). In order to fulfill this task they need a certain autonomy to operate independently from those they are to monitor. Public service broadcasters are vital for the media landscape in a democratic society, they gain a higher degree of autonomy than private media, which depend much more on the market and commercial considerations. This autonomy is vital to a democratic media environment as it enables a pluralistic approach towards opinions and topics as well as the participation of all groups in society in the public discourse (Curran, 2000).

Historically Public Service Broadcasting was justified on technical grounds (the lack of frequencies) and on the basis of an underlying philosophy grounded on normative values associated with western style democracy, including especially diversity, pluralism, universal service, and the maintenance of cultural identity (Steemers, 2001). Since broadcasting required frequency spectrum, and since these frequencies were limited in number, it proved necessary to lay down rules on how they were to be used if only to avoid having several broadcasters transmitting on one and the same frequency and thus causing interference in reception.

The second reason put forward for creating public broadcasters is related to the role assigned to radio broadcasting as a whole. This mode of communication raised questions practically throughout the world as to its usefulness and its potential. And the potential of radio seemed enormous, as did that of television later, from the political and from the social and cultural point of view. Equipped with a receiver, citizens could have access to instantaneous information, and to cultural products which they otherwise would have been unable to receive.

The question of how it should be organized in order to maximize its potential was a subject of debate. And broadcasting was perceived almost everywhere as an instrument of social and cultural development much more than as an economic activity. At the political level the capacity of radio broadcasting for informing citizens on state affairs was valued. It was also understood in many countries that if citizens were to be properly informed it should also be ensured that the political class did not control this medium for its own interest. Thus in these democracies it seemed to be necessary 
to guarantee the political independence of broadcasting. At the social level it was argued that broadcasting could fullfill certain roles, but the most important was doubtless its educational role.

The third reason preceding the establishment of public operators is more of the order of distrust with regard to the capacity of the market for fulfilling the public service mandate imposed on broadcasting. The firm belief that a public service function and other functions such as maximizing profits were totally incompatible for a broadcasting operator. It has been argued that these are still valid justifications for a public service role in the age of commercial pressures (Barnett et al, 2000). In practice, PSB may not have always attained these ideals. For example, there have often been failings in public accountability, and also a susceptibility to government interference, which raise doubts about the responsiveness of public broadcasters to public concerns (Barnett \& Curry, 1994).

\section{Brief History Of Public Service Broadcasting In KenYa}

Radio broadcasting in Kenya started in 1928 with a single channel targeting European settlers and providing news mainly from their countries of origin and other parts of the world. In 1953, the first radio broadcast service (African Broadcasting Services) was created for Africans, with programmes in Kiswahili, Dholuo, Kikuyu, Kinandi, Kiluhya, Kikamba and Arabic. Regional radio stations were set up in Mombasa (Sauti ya Mvita), Nyeri (Mount Kenya Station) and Kisumu (Lake Station).

In 1959 the Kenya Broadcasting Corporation was established by the British colonial administration with the objective of providing both radio and television broadcasting. Television was found likely to be financially self-reliant if it was set up as a fully edged commercial outfit. A consortium of eight European and North American companies was contracted by the colonial administration to establish the national television broadcasting system. By the end of 1962, a transmission station and recording studio had been set up, and television was officially launched in 1963 . When Kenya gained independence, the new government worried about the threat to national sovereignty posed by the foreign ownership of the broadcasting infrastructure. The Corporation was nationalized in June 1964, renamed Voice of Kenya (VoK) and became a department under the ministry of information, broadcasting and tourism (later renamed the ministry of information and broadcasting). Its new role, as the government mouthpiece, was to provide information, education and entertainment.

In 1989, the VoK was renamed the Kenya Broadcasting Corporation through the KBC Act, and accorded semi-autonomous status founded on the premise that it would adopt a more commercially oriented stance. Although the Corporation unveiled grandiose plans to expand news coverage and improve local programming content, it was unable to chart an independent editorial position, and it is still widely seen as part of the government propaganda machinery. Gradual liberalisation of the airwaves started in late 1989 when the government licensed the privately owned Kenya Television Network (KTN) to broadcast in Nairobi. This was a joint initiative of Kenya's ruling party, KANU, and London-based Maxwell Communications, but the British media group withdrew after the death of its founder, Robert Maxwell. Initially, KTN offered a mixture of re-transmissions of the American Cable News Network (CNN) programming and light entertainment, but over time evolved and now features local news bulletins and a few local productions. It was seen as a relief from the conformity previously on offer as it provided a different voice to the government-controlled Kenya Broadcasting Corporation (KBC). Currently the network derives most of its revenue from advertising and TV production services.

Gone are the days when KBC enjoyed the Government's goodwill through state funding and license fee. The corporation, has been left alone to battle it out with new private commercial stations which are edging it out of the cut-throat competitive broadcast sub-sector market. The genesis of the current situation could be traced back to the late 1980s and early 1990s when public service broadcasting were forced to change the trend of operation. The above trends led to a comprehensive privatization and investment in the broadcast sub-sector. This was accepted, not only as inevitable but also, as desirable. The process of liberalization and democratization of the airwaves in Kenya commenced with the enactment of the KBC Act (cap 221) No. 15 Of 1989 which transformed the then Voice of Kenya (VOK) into a semi-autonomous legal entity that would operate on commercial principles and thereby sustain itself in the emerging broadcast play-field. 


\section{Statement Of The Problem}

A paradigm shift is the most exigent option left to KBC, The public broadcaster cannot make it under the precent model. The deregulation of the media landscape poised a great challenge to the public service broadcaster. The organizational ability of the private media and their entrepreneurship skills in management, financial matters and competitive programming has switched audience from $\mathrm{KBC}$. Thus, new privately owned broadcasters target the affluent and young urban audiences with "foreign" or international popular music and entertainment as a way of attracting advertisement (Curran, 2002).

Broadcasting has become a business of profit driven production of programmes for consumption like any other commodity in the market. Considering that, the traditional role of the PSB was simply to disseminate government information, educate and provide some form of entertainment, it has become increasingly difficult for the same outfit to compete against the new profit driven private FM radio stations. Ove and above, $\mathrm{KBC}$ as a private broadcaster is unable to compete effectively in a liberalized market because of stifling legal and regulatory framework. Therefore, there is need for a new model for the PSB.

\section{THEORETICAL REVIEW}

The Liberal Pluralist Theory supports a press that is free and unencumbered by government or legislative oversight, the press is supposed to be the watchdog of the government and inform the polity of government policies while supporting the entrenchment of democracy. Curran (2000) notes that the media can be viewed in liberal theory as an agency of information and debate that facilitates the functioning of democracy. It also provides a channel between government and the people in political discussion and debate on issues that affect the polity.

Habermas (1964) concept of the 'public sphere' gives credence to this notion of the media. He supports the expectation that the mass media should facilitate pluralist debate and the free formation of public opinion. Therefore, a liberal pluralist theory of the media will support a free and independent press, which operates in the role of the public watchdog, while also playing the consumer representation role. With the media operating in the marketplace, it is assumed to thereby reflect popular concerns and finally performing an informational role. This amplifies the media's role in a democratic setting. Curran (2000) notes that media theorists generally view any government attempt at intervention in or regulation of the media with deep suspicion and emphasize that the media's critical surveillance of government is fundamental to the functioning of a democracy. This collaborates with perspectives from Dominick (2005) who note that "it is important for the press to check the excesses of the government in a representative democracy as it will keep the government representatives accountable to the electorate". In a developing economy such as South Africa, the media's role becomes central to the proper functioning of the system.

\section{FINDINGS}

It was observed that Kenya Broadcasting Corporation as a Public Service Broadcaster is a creature of the government, either as a part of the Ministry of Information or Communications, or as an independent, state-owned enterprise with funding directly from government resources. The respondents stated that the mission of PSBs is almost universally to inform, educate and entertain the public. Other minority objectives include training, cultural development and reporting government activities.

According to the findings the main limitations to the growth of Kenya Broadcasting Corporation are financial. Funds are needed both for developing the necessary infrastructure, capital investment, as well as for trained personnel, training, programme production and maintenance (of old or obsolete equipment) where the PSB is frequently unable to obtain replacement parts. It was also observed that, operational/political bureaucrac are hindrances to further development of Kenya Broadcasting Corporation.

It was observed that commercial competition has provoked a considerable decline in Kenya Broadcasting Corporations audience share, particularly in television broadcasting. KBC is facing the contradictory requirements of having to maintain the public charter of programmes as well as competitiveness. 
Commercial broadcasting operators have taken away the broadcasting rights, advertising revenues, audience share and Public Broadcasting Services' legitimacy in the political debate. The findings reveal that Kenya Broadcasting Corporation was faced with challenges and dilemmas from at least five directions: market forces have been favoured by ideological and political tendencies in an age of "information capitalism", and the competition makes Kenya Broadcasting Corporation appear as a liability on the public purse; rising costs and inflation, taken together with falling revenue from licensing and loss of market share, have greatly tested government's commitment to provide continued adequate funding.

It was observed from the findings that the ideal of Kenya Broadcasting Corporation as a mainstay of indigenous culture is undermined by the disparity between the low cost of imported programmes and the high cost of indigenous productions, and lastly on impartiality and political independence, the traditional commitment of public service broadcasting, have come under stress, not only in less developed and transitional societies, but also in prosperous "first world" countries.

The autonomy of public service media is not unconditional, but rather characterized as a situation of external dependency where different actors try to influence their operations. Politics is without doubt the most influential factor on the conditions of public service media. Political arrangements define supervision mechanisms of public service media and the accountability measures with regard to content

\section{CONClusion}

In conclusion there is potential to turn around Kenya Broadcasting Corporation into a truly PSB and be adored by all audiences. This study having identified management, programming and finance as the main three predictor factors influencing the performance of Kenya Broadcasting Corporation, it is now incumbent on the government to put in place policy, legal and regulatory framework to guide the same.

Policy declarations on public service media generally support a broad mission and a great variety of programme genres to meet diverging demands from societal interests. At the same time, it is clear that the political perceptions of public service remit in practice sometimes differ from the principles stated.

\section{REFERENCES}

[1] Bardoel, J. and Lowe, G. F. (2007) From Public Service Broadcasting to Public Service Media. The Core Challenge, In Bardoel, J. \& Lowe, G. F. (eds.): From Public Service Broadcasting to Public Service Media, RIPE@2007. Göteborg: Nordicom,

[2] Begoyan, A. (2009) State versus private ownership: A look at the implications for local media freedom: Paper submitted by ARTICLE 19 to a conference on freedom of expression in the local press, the rules of free competition and media pluralism in October 2009, convened under the Observatory of the Freedom of Media in Poland, a joint project of the Helsinki Citizens Assembly, Human Rights House and ARTICLE 19.

[3] Barnett, S et al. (2000) E-britannia The Communications Revolution. Luton: University of Luton Press.

[4] Barnett, S. \& Curry, A. (1994) The Battle for the BBC. London: Aurum Press.

[5] Curran, J. (2002) Media and Power, Routledge Taylor \& Francis: New York

[6] Curran, C. and Gurevitch (2000), Mass Media and Society, London: Arnold/Oxford University Press.

[7] Donders, K. (2012). Public Service Media and Policy in Europe, Basingstoke: Palgrave

[8] Dominick R J. (2005), The Dynamics of mass Communication; Media in Digital Age (8th Edition), New York: McGraw Hill.

[9] Doyle, Gillian. 2002. Understanding Media Economics. London: Sage.

[10] Fourer, J (1997), News Values: Ideas for an Information Age, University of Chicago Press, Chigaco

[11] Kenya Communication Act (2008), Republic of Kenya, Government Printer, Nairobi

[12] Lowe, G. F. (ed.) (2010). The Public in Public Service Media, Gothenburg: Nordicom. Lowe, G. F. and Martin, F. (eds.) (2014). The Value of Public Service Media, Gothenburg: Nordicom.sep?

[13] Trappel, Josef et al. (eds.): Media in Europe Today. Bristol (Chicago) : Intellect, 2011.

[14] Phillips, P. (2000), Ownership and Control of Media excerpted from War, Lies \& Videotape, International Action Centre, USA 
Rethinking Public Service Broadcasting in the Age of Economic Pressures. A Case Study of Kenya Broadcasting Corporation.

[15] Steemers, J. (2001) In Search of a Third Way: Balancing Public Purpose and Commerce in German and British Public Service Broadcasting. Canadian Journal of Communications

Citation: Mr. Wafula Nyongesa. "Rethinking Public Service Broadcasting in the Age of Economic Pressures. A Case Study of Kenya Broadcasting Corporation". International Journal of Media, Journalism and Mass Communications (IJMJMC), vol 7, no. 3, 2021, pp. 01-05 doi: http://dx.doi.org/10.20431/24549479.0703001.

Copyright: (C) 2021 Authors. This is an open-access article distributed under the terms of the Creative Commons Attribution License, which permits unrestricted use, distribution, and reproduction in any medium, provided the original author and source are credited. 